\title{
Unravelling economic dependence and independence in relation to island sovereignty: The case of Kalaallit Nunaat (Greenland)
}

\author{
Adam Grydehøj \\ School of Tourism Studies, Guangzhou University, China \\ Institute of Island Studies, University of Prince Edward Island, Canada \\ agrydehoj@islanddynamics.org
}

\begin{abstract}
Economic challenges are often invoked in discussions of island sovereignty and nonsovereignty. This paper explores the perceived link between a subnational island jurisdiction's ability to achieve economic independence and its ability to achieve political independence. In the popular and political discourse, it is frequently argued that island territories - sovereign island states and subnational island jurisdictions (SNIJs) — ought to reduce their economic dependence on patron states. Such ideas are often entangled in colonial relationships, and the scholarship suggests no correlation between economic independence and political sovereignty. I use the case of Kalaallit Nunaat (Greenland) to illustrate the conceptual complexity and ambiguity of economic dependence and economic independence. Media and political discourses emphasise that because Kalaallit Nunaat is economically dependent on its former coloniser Denmark, this SNIJ is incapable of exercising its autonomy or becoming a sovereign state, yet these discourses simultaneously argue that Kalaallit Nunaat should not create economic dependencies on other states, such as China and the USA. This discursive construction ignores the real power dynamics at play in the relationships between Kalaallit Nunaat, Denmark, and other states. I argue that the concepts of economic independence and economic dependence are unsuitable as indicators of readiness or unreadiness for island political independence.
\end{abstract}

Keywords: economic dependence, islands, Kalaallit Nunaat (Greenland), political independence, sovereignty, subnational island jurisdictions (SNIJ)

https://doi.org/10.24043/isj.101 • Received June 2019, accepted September 2019

(C) 2020-Institute of Island Studies, University of Prince Edward Island, Canada.

\section{Introduction}

This paper explores the perceived link between a subnational island jurisdiction's ability to achieve economic independence and its ability to achieve political independence. I use the case of Kalaallit Nunaat (in English, 'Greenland') to illustrate the conceptual complexity and ambiguity of economic dependence and economic independence, and I argue that these concepts are unsuitable as indicators of readiness or unreadiness for political independence, however this may be defined.

I begin with a note on methodology and my position as a researcher. Next, I review the literature concerning island sovereignty and non-sovereignty, followed by the literature on 
economic dependence and independence in island territories. I then introduce the case of Kalaallit Nunaat and show how concepts of economic dependence and independence have been understood there, granting particular attention the recent controversies over an airport expansion project and USA President Donald Trump's desire to purchase the territory. I then analyse how these understandings are frequently paradoxical and unproductive for island territories. I ultimately argue that the creation of new forms of economic and political dependence can simultaneously be conceived of as engagement in economic and political independence.

\section{Positioning and methods}

I am neither Danish nor Kalaallit (Greenlandic Inuit) but am instead American. Whatever insight into local conditions I possess is a result of having lived 17 years in Denmark and having spent 22 weeks in Kalaallit Nunaat over the course of seven visits between 2014-2018. This distance permits me a perspective outside Kalaallit Nunaat's dominant cultural and ethnic divides, though it also means there are elements of the Danish and Kalaallit cultures that I do not understand. I speak Danish (the primary language of Denmark and the second language of Kalaallit Nunaat), but I do not speak Kalaallisut (the primary language of Kalaallit Nunaat). As such, I lack direct access to certain kinds of local debates and discussions that may be held solely in Kalaallisut. Given that Kalaallit Nunaat's news media is dominated by the Danish language (Villadsen, 2016), Kalaallit-oriented discussions of current affairs furthermore occur more frequently in the private sphere or in semi-public contexts, such as on Facebook or 'below the line' on the Sermitsiaq.ag newspaper website.

This paper is based on a qualitative media content analysis of mass media news reports (both print and online) and scholarly writing (Macnamara, 2005). It is unavoidably informed by my own experiences and prior research in Kalaallit Nunaat, including semistructured ethnographic interviews and the teaching of six courses at Ilisimatusarfik/University of Greenland's Department of Political Science. These experiences add anecdotal knowledge but are not claimed to provide the same kinds of data as would new, focused fieldwork. In order to adjust for this limitation, I used an iterative research process in which I solicited feedback from local community members and academic experts at various stages of the research and writing process and adjusted my research questions and terminology accordingly (Agee, 2009). This approach is influenced by the importance of reflexive acknowledgment of one's own position as a researcher, particularly in postcolonial contexts (Grydehøj, 2018b).

With this article, I do not seek to argue for or against Kalaallit Nunaat's political independence, for or against any particular development projects, or for or against economic engagement with Denmark or other states. My focus is instead on assessing the ways in which these policy areas are being discussed.

The present paper builds upon the article 'Decolonising the economy in micropolities' (Grydehøj, 2018a), which uses Kalaallit Nunaat as a case to argue that economic processes in very small territories have different dynamics than in larger territories and that sovereign or nonsovereign status is ultimately not of fundamental importance in determining a micropolity's economic success or ability to make its own political decisions. The present paper takes as its unit of analysis 'small islands', a term that is widely used in both the academic literature and in practice (for example, by the United Nations' Small Island Developing States grouping) but for 
which there is no consensus definition. Ratter (2018, p.18) notes that smallness in terms of land area or population is relative, using the example of Kalaallit Nunaat to show that even the socalled "largest island on Earth" can be regarded as a 'small island' on account of its small population. As argued previously, there are grounds for focusing on polities with populations under 100,000, given that island territories with populations below this threshold "seem to be subject to different economic dynamics related to trade openness and governmental status than are larger-but still small-polities" (Grydehøj, 2018a, p.72).

\section{Island sovereignty and non-sovereignty in the early $21^{\text {st }}$ Century}

Around the world, there are many island territories, including both subnational island jurisdictions (SNIJs) and sovereign island states (SISs). After the creation of numerous SISs in the four decades following the end of World War II, the movement between these two categories of jurisdiction has largely ceased (McElroy \& Parry, 2012). Since the early 1980s, no islands and archipelagos that became sovereign states have reverted back to non-sovereignty, and only two SNIJs have become SISs (Palau in 1994 and Timor-Leste in 2002).

Various hypotheses have been advanced to explain why today's SNIJs are not generally moving toward sovereignty. It could be a matter of economic self-interest, with ties to a metropolitan state (often a former coloniser) providing a safety net or steady supply of resources - or from another perspective, a lack of economic capacity and extant skills may prevent SNIJs from making the leap from non-sovereign to sovereign status, given the additional responsibilities that seem concomitant with acting like a state in today's world (Ferdinand, Oostindie, \& Veenendaal, 2020; Pöllath, 2018). It could be that island populations simply are not interested, that sovereignty has lost its cachet (Baldacchino \& Hepburn, 2012). Sometimes the demographic impacts of settler colonialism complicate Indigenous efforts to exercise selfdetermination, as is the case in New Caledonia (Korson, 2018), which held an independence referendum in 2018. Some metropolitan states actively seek to counter (through legal obstacles, military coercion, or simply economic enticements) independence movements in their SNIJs, as exemplified by China's efforts to resist greater local decision-making power in Hong Kong (Yuen, 2015) and Papua New Guinea's decades' long attempts to retain control over Bougainville (Ghai \& Regan, 2006). Different combinations of these factors are at play in different SNIJs.

Furthermore, a scholarly consensus has emerged over the past two decades that a binary and absolute understanding of sovereignty and non-sovereignty is misleading. Agnew (1994) influentially challenged the link between sovereignty and territory-and thus the foundations of Westphalian sovereignty itself. Authors such as Grimm (2015), Sassen (2008), and Appadurai (1996) explore the historical contingency and specificity of the concept of sovereignty and how its survival is fundamentally challenged by processes of globalisation. Bonilla (2017, p.332) regards the concept of sovereignty "as a discursive figure produced through the colonial encounter" rather than as "a measurable quality of states" that is currently under threat from globalisation. Pugh (2017) observes designations of sovereignty as being undermined by everyday practices of empowerment and disempowerment. Alberti and Goujon (2020) see sovereignty as occupying a spectrum, with many nominally sovereign states lacking what the authors regard as key markers of sovereignty, such as diplomatic representation and monetary 
control. Baldacchino (2010) and Baldacchino and Milnes (2009) explore a productive tension between sovereignty and non-sovereignty that can empower island territories. It is thus widely recognised that political dependence (affiliated territory status) and political independence (sovereign state status) (henceforth collectively, 'the political dependence/independence binary') are not actually existing, real entities: no territory is fully politically dependent, and no territory is fully politically independent.

It is nevertheless intriguing that, as shown below, there exists a popular and political discourse that dichotomizes economic dependence and economic independence (henceforth collectively, 'the economic dependence/independence binary'). This popular and political discourse furthermore creates a link between the political and economic dependence/independence binaries, positing them as mutually constitutive.

\section{The paradox of economic dependence/independence}

Comparative research has consistently shown that SNIJs outperform SISs economically (Baldacchino, 2010; McElroy \& Pearce, 2006; Armstrong \& Read, 2003). Thus, while a strong economy may be preferable to a weak one, a strong economy is clearly not a precondition for the exercise of island sovereignty. The question then arises whether islands may confront a tradeoff between political independence and economic strength.

Recent research by Bertram (2015) complicates attempts to assess the results of island nonsovereignty: although SNIJs generally boast better economic and social performance than do SISs, today's SNIJs also performed better than today's SISs prior to the latter gaining independence. The key seems to be that smaller and less populous island territories were both less likely to become independent and more likely to experience close economic and administrative integration with the colonising/metropolitan state, with the latter tendency itself being associated with superior performance. In other words, it is not that becoming politically independent causes island territories to perform worse; it is instead that the smallest of island territories were historically more likely to benefit from metropolitan links and more likely remain non-sovereign.

Generally speaking, both SNIJs and SISs tend to remain dependent on economic contributions from larger states. As Levine (2012, p.445) notes:

All Pacific Island countries are significant aid recipients, their independence, state apparatus and means of government all heavily subsidised by external sources-with China, Taiwan, Japan, New Zealand, Australia, France, the USA, the European Union, and others, each making their own contributions to different groups of islands, most of them endowed with the legal attributes of sovereignty and formal independence.

Yet beyond the lived reality, there is the realm of expectation: how do people expect or desire island economies to work? The economic dependence/independence binary comes into play here, for it is not simply posited that politically independent islands should have strong economies (which is, after all, an aim for both sovereign and non-sovereign territories); it is more specifically posited that politically independent islands should have independent economies. Workable definitions of what 'economic independence' means on a state or territorial scale are, however, 
lacking. As authors such as Frank $(1969,1967)$ and Cardoso and Faletto (1979) argued in the 1960s and 1970s, 'dependency' is a result—not a symptom-of power imbalances: underdevelopment was caused by colonialism and thus cannot be solved by the application of even more colonialism.

Within island studies, groundbreaking work on island economic dependency was undertaken by Bertram and Watters $(1984$, p.88) who decry "dogmatic condemnations of so called 'dependency'," linked to:

the nationalist fallacy of assuming that Island societies are bounded geographic national entities, rather than organic parts of a wider economic system from which on balance they derive substantial benefits. (The nationalist argument against 'dependence' has always, after all, been the ad hoc one that the 'nation' is worse off in some meaningful sense as a result of its economic linkages, and that abandoning or modifying those linkages is the key to improvement) (Bertram \& Watters, 1984, p.88).

One commonly accepted marker of economic dependence is an island's reliance on aid or other forms of direct monetary transfers or contributions from another state or territory, including official development assistance (ODA), direct budget support, purchase of fishing quotas, aid in return for military presence, or payment for more sophisticated deployments of jurisdictional capacity. Because SNIJs and SISs have proved particularly adept at accruing and attracting such transfers (Grydehøj, 2018a), it disproportionately harms island territories when these transfers are assessed as an illegitimate or unwanted source of income.

Bertram and Watters (1984, p.117) label the policy aversion to aid-funded island expenditure as "the protestant ethic view, widely held in official circles, that incomes and consumption should be tied to productive activity, and that in order to 'deserve' aid, countries must demonstrate a willingness to work." Poirine (1998, p.76) too notes this "moral interference," which prefers island aid "used for investment" to island aid "used for private or public consumption," even when the motivations of the aid givers are not just altruistic but also geostrategic. This 'donor' emphasis on investment over consumption enhances donor control over how funds are used, potentially reproducing metropolitan or continental values over needs recognised by islanders. As a result, economic reliance on even stable monetary flows is often cast as entrenching dependence, regardless of whether island governments actually control the manner in which and policy areas on which these funds are spent.

The corollary of an insistence on economic independence is often a focus on primary sector production and import substitution (Bertram \& Watters, 1984), with import substitution strategies reducing reliance on external actors and with the sale of primary commodity exports conceivably representing a locally grounded means of generating foreign exchange. Of course, primary commodity exports are no less dependent upon relationships of trade with external actors than are sales of tertiary sector products and strategic services such as payments in return for military presence. Furthermore, as we shall see below, even primary commodity exports are frequently enmeshed in colonial discourses of exploitation (Emel, Huber, \& Makene, 2011).

In the next section, I will show how the economic dependence/independence binary has been expressed in discourse concerning Kalaallit Nunaat. 


\section{The case of Kalaallit Nunaat}

Kalaallit Nunaat is an SNIJ of Denmark. This former colony-with a population of around 56,000 , nearly $90 \%$ of whom are Indigenous Kalaallit - is a strongly autonomous territory. It has its own parliament (elected by proportional representation) that exercises legal authority over most major policy areas, with significant exceptions being immigration, defence, and foreign affairs. Kalaallit Nunaat has a legally grounded trajectory toward political independence, with the Danish parliament's 2009 Self-Government Act setting out the manner in which Kalaallit Nunaat can become politically independent at a time of its own choosing.

The exercise of and legal basis for Kalaallit Nunaat's present-day autonomy and potential political independence thus exist separate from any economic determinations. While economic conditions may affect how Kalaallit Nunaat's government operates, economic status does not determine the territory's political status. Nevertheless, the international scholarly consensus that SISs and SNIIJs tend to possess complex economic dependencies, discussion within both Denmark and Kalaallit Nunaat itself concerning Kalaallit Nunaat's political status is intimately tied to arguments regarding the economic dependence/independence binary.

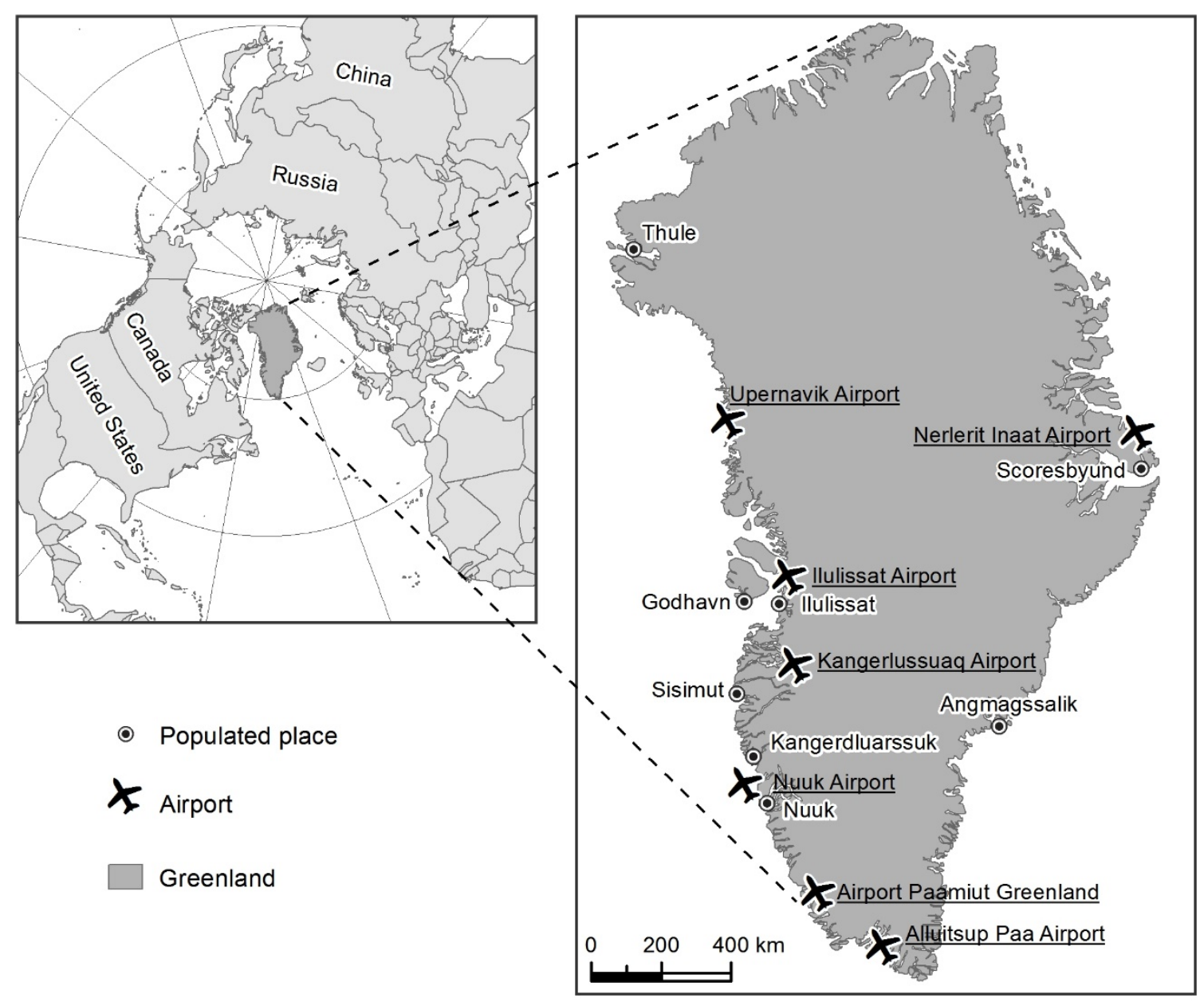

Figure 1: Map of Kalaallit Nunaat and its airports. Source: (C) Derek Wu, 2019. 
Kalaallit Nunaat's political and administrative environment

Kalaallit Nunaat was colonised by Denmark-Norway in 1721 and has remained under Danish jurisdiction ever since-bearing in mind that the $18^{\text {th }}$-Century Kalaallit were given no say in the matter. Kalaallit Nunaat was never a site of settler colonialism and was instead administered by Denmark to maximise resource extraction, particularly in the form of seal skins. The early decades of the 1900s saw an industrial shift toward commercial fishing. In 1953, following limited consultation with the educated Kalaallit elite (Olesen, 2017), the Danish government nominally 'decolonised' Kalaallit Nunaat by integrating the territory into the Danish state as a municipality. This represented a transition from open colonialism to 'hidden' colonialism, and the following two decades witnessed rising Kalaallit nationalism, especially among young Kalaallit educated at Danish universities (Hansen, 2017, p.61). Increasing demands for political authority led to the creation of the Home Rule system in 1979.

In terms of de jure distributions of authority, the Home Rule system granted Kalaallit Nunaat the potential for significant autonomy, though it did not grant Kalaallit Nunaat ownership over subterranean natural resources. Negotiations between the governments of Denmark and Kalaallit Nunaat in the 2000s resulted in a 2008 referendum in Kalaallit Nunaat regarding the introduction of a more powerful Self-Government system (75.5\% in favour), followed by the Danish parliament's adoption of the Self-Government Act in 2009 (Lov om Gronlands Selvstyre, 2009).

The transition from Home Rule to Self-Government has not necessarily had much effect on the life of the average Kalaallit Nunaat resident (Villadsen, 2016, p.12), yet a key aspect of the new Self-Government system is that it laid down a pathway by which Kalaallit Nunaat could become independent from Denmark at a time of its own choosing. Whereas the 1979 Home Rule system had involved an annual block grant that increased as responsibility for additional policy areas were transferred from the Danish state to the Kalaallit Nunaat state, the 2009 SelfGovernment system froze the block grant at then-current levels (adjusted for inflation, 3.6 billion Danish kroner, around $€ 483$ million) so that the devolution of new responsibilities would not result in increased monetary contributions from Denmark. It was hoped this would be offset by the ability to profit from Kalaallit Nunaat's subterranean mineral resources. Indeed, the SelfGovernment Act ties the block grant directly to subterranean resource extraction, stating that when Kalaallit Nunaat achieves profits from these activities, the subsequent year's block grant will be reduced by an amount equal to half the level of profits exceeding 75 million Danish kroner. In the event that these reductions ever equal or exceed the block grant, then the Danish and Kalaallit Nunaat governments must negotiate "future economic relations between the Kalaallit Nunaat Self-Government and the [Danish] state, including regarding distribution of income from natural resources activities in Greenland" (Lov om Gronlands Selvstyre, 2009, \$4.10; translation my own).

These legal mechanisms would neither force political independence upon an economically independent Kalaallit Nunaat nor deny the people of Kalaallit Nunaat the ability to opt for political independence in the absence of economic independence. However, one result of the way in which the Self-Government Act was constructed has been to create a conceptual association between independence and extractive industries (especially mining). Active mining projects remain scarce though, and a rapid, mining-fuelled transition to 'economic independence' seems unlikely (Committee for Greenlandic Mineral Resources to the Benefit of Society, 2014). 
Kalaallit Nunaat remains highly dependent on Denmark. The block grant represents around 25\% of Kalaallit Nunaat's GDP (Naatsorsueqqissaartarfik, 2017, p.2). Furthermore, although all of Kalaallit Nunaat's nationally elected politicians are of Kalaallit ethnicity, the bureaucracy, educational system, and business community remain highly dependent on imported Danish knowledge and skilled labour, leading to a prevalence of Danish policy solutions to Kalaallit problems (Grydehøj, 2016b; Grønvold Samuelsen, 2010). The result is a "translated Greenland" (Villadsen, 2016, p.5; translation my own), in which most laws, news communication, and daily interactions with the public sector are mediated through Danish language, culture, and customs. For many Kalaallit, these cultural factors heighten the feeling that the territory remains in a colonial relationship.

\section{The economic dependence/independence binary in Kalaallit Nunaat}

Surveys undertaken within Kalaallit Nunaat in the past few years suggest that residents of Kalaallit Nunaat generally interpret the SNIJ's economic dependence in a different manner than do economists, politicians, media commentators, and the general public in Denmark.

A 2016 survey found that 64\% of Kalaallit Nunaat respondents feel that political independence from Denmark is either very important or somewhat important to them, compared with $24 \%$ who do not feel that political independence is particularly important (Skydsbjerg \& Turnowsky, 2016). These results were tempered, however, by a subsequent survey, which found that $44 \%$ of respondents only desire political independence if it can be achieved without negatively impacting the economy, compared with $11 \%$ who desire political independence regardless of economic impacts, and 12\% who can accept a slight worsening of the economy (Turnowsky, 2017a). This seemed to lend weight to the frequent warnings from Danish commentators that Kalaallit Nunaat would struggle to afford political independence and that a politically independent Kalaallit Nunaat would not receive assistance from Denmark (e.g. Turnowsky, 2017; Ritzau, 2018c; Rottbøll, 2018; Hannestad, 2014). Yet further surveys undertaken in 2018 find not only that $67.7 \%$ of adults living in Kalaallit Nunaat desire political independence but also that $43.5 \%$ of respondents believe that political independence will actively have a positive or very positive effect on the economy-that is, economic expectations in Kalaallit Nunaat and Denmark seem fundamentally different (Breum, 2019).

Although the recent surveys offered the first quantitative evidence of these differences in outlook, the differences themselves have long been recognised. Over a decade ago, Carlsen (2008, p.39; translation my own) argued that:

The public debate concerning Greenland's development has in recent years been dominated by a narrow economic rationale, in which social and culturally relativistic arguments are almost by definition written off as 'obsolete' or as an expression of 'national romanticism'. Two related aspects characterise the dominant rationale:

- People make light of the fact that Greenland is a composite society and an Arctic periphery region and choose in a Eurocentric manner to regard Greenland like "any other private business" (Fællesudvalget, 2003: 10) and to make normative comparisons with Denmark, the Nordic region, and other OECD countries.

- Market liberalism or neoclassical thinking tend to be applied, despite the fact that, even on the terms of this rationale, it is doubtful whether it is possible to create 
functioning markets with multiple competing actors in all settlements or for certain products and service providers in a country with approximately 57,000 residents. The autonomy discourse is also affected by a degree of economic determinism, given that a narrow focus is placed on economic growth as a prerequisite for societal development.

Despite the transition from Home Rule to Self-Government, not much has changed on a discursive level in the intervening years.

This kind of thinking was highly evident in the 2019 edition of the Greenland Business Association's (Gronlands Erhverv) biennial Future Greenland conference. The theme of the 2019 conference was 'Economic independence and political autonomy: What will it take?', which was described as follows:

A much stronger national economy is the basic prerequisite for achieving greater political autonomy, both within the possibilities of the current framework of the Government of Greenland, and especially if the vision of Greenland as an independent nation is to be realised. [...] What does economic independence mean in an increasingly globalised world, in which the trade of all countries in goods and services and the increasing mobility of labour makes everyone dependent on everyone else, and the giants on the internet cross all borders? What kind of economic growth would be required for the national treasury to be able to manage without external financial support? How large is the welfare gap, with and without block subsidies? What conditions will foreign investors impose, if they are to be willing to take on commercial risks? [...] What does political autonomy mean, if a country cannot be economically independent? What is autonomy in a world of different regional, national security and trade policy interests and alliances? [...] What will be really be required in concrete terms in order to allow Greenland to one day declare itself economically independent and politically autonomous? (Greenland Business Association, 2019)

For the Greenland Business Association, an employers' association, economic independence and political autonomy are inseparable. We can discuss what the terms mean and how best to achieve them, but we cannot question whether economic independence truly is a "prerequisite" for political autonomy. Furthermore, it is taken for granted that "external financial support" and "block subsidies" are inimical to economic independence. This approach also presents a political dependence/autonomy binary, reinforcing Kalaallit Nunaat's lack of political power. Openmindedness regarding what economic independence means and how it may relate to political autonomy and independence is thus strictly limited. By reproducing and linking these binaries, the Greenland Business Association (no doubt unintentionally) implies that Kalaallit Nunaat's claims to present-day autonomy are overstated. Making any political autonomy or independence contingent upon replacing external financial support (rather than accepting support, reducing spending, fundamentally altering economic policy, etc.) narrows the vision for potential Kalaallit Nunaat futures.

This line of thought from the Greenland Business Association is just one example of how the economic dependence/independence binary and political dependence/independence binary 
can be paradoxically deployed to prevent the conceptualisation of transitions from one state of being to the other. I do not mean to suggest that people who and organisations that engage in this kind of binary thinking are necessarily incorrect in their wider analyses or that they do not genuinely wish Kalaallit Nunaat well. Many excellent researchers take this approach. I simply suggest that this approach reflects a certain manner of thinking about the economy and political independence, a manner of thinking that manages to shut down the debate in the process of opening it.

'Economic dependence' (økonomisk afhangighed) and related concepts such as 'economically self-sufficient' (økonomisk selvborende) (Wennecke, Jacobsen, \& Ren, 2019) are commonly used in popular, political, media, and administrative discussions in both Kalaallit Nunaat and Denmark concerning the former's relationship with the latter and its prospects for political independence. Some examples (in chronological order) include:

After 23 years' Home Rule, Kalaallit Nunaat has become an adult man and wants to move away from home. But he doesn't want to lose out on his allowance. Experts say it is completely unrealistic and hypocritical to demand Self Government and political independence when the economic dependence on Denmark is so obvious and enormous (Information, 2002; translation my own [editorial in Danish newspaper]).

Because of the broad political aspiration for more political independency from Denmark and as economic independency is an essential precondition to political independency the politicians are searching for alternative ways to generate revenues for the country (Hansen, 2013, p.86 [academic paper]).

Without reforms, Kalaallit Nunaat will never be economically self-sufficient, and the country will remain stuck in economic dependence on others (Økonomisk Råd, 2014, p.18; translation my own [report from Kalaallit Nunaat's Economic Council]).

"We want independence." This was the clear message from Siumut leader Aleqa Hammond just about one year ago, before she was elected prime minister [of Kalaallit Nunaat]. But according to a new report prepared by 13 Nordic researchers [...], Kalaallit Nunaat will be economically dependent on Denmark for many years to come (Sermitsiaq, 2014; translation my own [report in Greenlandic newspaper]).

Pointed statements on the other side of the Atlantic after the recent election raise the question as to whether talk of an independent Greenland is realistic? That sort of thing resembles a kind of 'campaign candy' [valgspaek, a pun in Danish] since nothing much will happen with the independent economy after the election (Winther, 2018; translation my own [opinion piece in Danish newspaper]).

The political goal is for Kalaallit Nunaat and its population to take as much responsibility as possible. It is sought after for Kalaallit Nunaat to in the future become both economically and politically self-sufficient in order to give the Kalaallit people the right to decide for themselves (Vittus Qujaukitoq, qtd. in Kristensen, 2019b; translation my own [statement from a Kalaallit politician]). 
The first of the above examples is strikingly paternalistic and belongs to the tradition of "the Danish self-image of altruism," which indulges in "the mother-child metaphor [...] well known from European imperial projects" (Gad, 2017, p.36). All these examples, however, suggest a largely unexamined conceptual association between the economic dependence/independence binary and the political dependence/independence binary. As Bjørst and Ren (2015, p.92) note, due to the Kalaallit focus on gaining "economic independence from the Danish commonwealth," an array of topics come to be "embedded (in discourse) in the ongoing nationbuilding process in Greenland" (see also Wennecke, Jacobsen, \& Ren, 2019).

This same framing is present in the 2009 Self-Government Act, which takes for granted that Kalaallit Nunaat is aiming for economic independence and which makes the ability to continue to be economically dependent (i.e. receiving the block grant) conditional upon the lack of a particular kind of productive activity (primary sector exploitation of subterranean resources). There is nothing inherently wrong with seeking to reduce dependence on or seeking to discontinue the block grant, but it is odd that this course of action is taken as givenultimately reducing the ability of the people of Kalaallit Nunaat to make informed decisions. As we shall see below, although popular and political opinion in both Denmark and Kalaallit Nunaat expresses the latter's economic dependence on the former as negative and to some extent illegitimate, the Danish government has made strong efforts to maintain this relationship of economic dependence.

The perceived relationship between the political and economic dependence/independence binaries also emerges in the interplay between academic research and the media. For example, in June 2019, Agneman (2019, p.1) posted in the SSRN academic repository a draft paper studying how voters respond when presented with "pessimistic economic information" regarding Kalaallit Nunaat's "fiscal dependency on the current political union." Despite its carefully worded narrow conclusions concerning voter "malleability" (Agneman, 2019, p.28) in the face of information explicitly selected for bias, the paper was interpreted as making a much broader point. In the weeks following its online publication, the paper became a frequent reference point in the Kalaallit Nunaat media, beginning with the national broadcaster KNR, which presented the article as discussing "how much it affects the population to have information on economic expectations before they make up their mind about the question of independence" (Lindstrøm, 2019; translation my own). This same approach was taken by the newspaper Sermitsiaq, which ran the headline 'Breaking away from Denmark has a price: If one is informed about the economic consequences of independence, one is more likely to vote against an independent Greenland' (Juncher Jørgensen, 2019b; translation my own). Indeed, the interpretations of Agneman's conclusions seemed to become broader with each iteration: the paper was subsequently used to add urgency to discussions concerning how the block grant might be cancelled out (Kristensen, 2019c). I do not believe that the media intentionally misrepresented Agneman's research; this instead seems to be a case of media actors reading into the research the kind of information and conclusions that they expected encounter.

Next, we shall discuss two prominent and interrelated examples of the discursive interplay between the political and economic dependence/independence binaries in Kalaallit Nunaat. 


\section{Airport development and Donald Trump}

The conceptual binaries received significant discussion in 2018-2019 debates surrounding airport development in Kalaallit Nunaat and the August 2019 revelation that USA President Donald Trump wished to purchase Kalaallit Nunaat from Denmark.

Costly, time-consuming, and unpredictable transport conditions, occasioned by difficult logistics and past decisions regarding infrastructure, have long been perceived as an obstacle to Kalaallit Nunaat's economic development-and by extension, to it someday becoming a sovereign state. Successive Kalaallit Nunaat governments have asserted an intention to expand or replace a number of the SNIJ's existing airports. Over the course of 2018, a number of decisions were made by the Kalaallit Nunaat government (Naalakkersuisut, 2018) that resulted in work getting underway on the so-called 'airport package'. The airport package approved the creation of international airports capable of handling large planes in Nuuk and Ilulissat as well as an improved regional airport in Qaqortoq. The state-owned enterprise Kalaallit Airports Holding (2019), established in 2016, is responsible for building, owning, and operating these three airports.

These plans have proved highly controversial, prompting opposition of different kinds from many residents of Kalaallit Nunaat. However, discussing the precise grounds for Kalaallit support for or opposition to the airport package as such (disagreements over its effects on quality of life in Nuuk, its contributions to trends of population concentration, its precise choice of locations and timings for airport construction, etc.) is outside the scope of this paper.

From the start, the airport package met with criticism, not just from segments of the population in Kalaallit Nunaat itself but also from politicians and the media in Denmark. For example, Søren Espersen, Kalaallit Nunaat spokesman for the Danish People's Party, linked the Kalaallit Nunaat government's airport package with its desire for political independence and suggested that the SNIJ was "heading for economic collapse" (qtd. in Ritzau, 2018a; translation my own). Generally speaking, the airport package was regarded by Danish commentators as yet another Kalaallit Nunaat vanity project, pursued by independence-obsessed politicians who were profligate with Danish money.

In March 2018, Kalaallit Airports prequalified six potential contractors for construction work on the airports: one Dutch company, one Canadian company, one joint Danish-Icelandic bid, two Danish companies - and one Chinese company, China Communications Construction Company (CCCC) (Ritzau, 2018b). The prequalification of CCCC prompted serious concern across Denmark's political divide. Then-prime minister Lars Løkke Rasmussen (Liberal Party) suggested:

Investments in airport projects of the magnitude we're discussing here of course raise some questions and may-depending on financing and selection of external business partners-have foreign affairs dimensions, which the [Danish] government will discuss with the [Greenlandic] government. (qtd. in Ritzau, 2018d; translation my own)

Furthermore, Nick Hækkerup (Social Democrats), then-Foreign Affairs spokesman for the main opposition party, warned: 
The Greenlanders shouldn't ally themselves with the Chinese. They should be incredibly careful that they don't end up in the pockets of the Chinese. Elsewhere in the world, we've seen the Chinese use contracts to exploit countries. [...] Because of that, Denmark should intervene if Greenland makes itself dependent upon the Chinese. (qtd. in Ritzau, 2018f; translation my own).

These and other statements by Danish politicians and commentators may reflect legitimate Danish geopolitical concerns with regard to China, but they also express a worldview in which Kalaallit Nunaat must not simply switch its economic dependence on Denmark with economic dependence on other states. Thus, for example, Henrik Breitenbauch, Head of University of Copenhagen's Centre for Military Studies, remarks, "My assessment is that there is no longer an innocent path to independence. If Greenland leaves the Danish Realm, then the country will step straight into dependence on the USA" (qtd. in Turnowsky, 2019a; translation my own).

The statement by Lars Løkke Rasmussen quoted above contains an implicit threat that the Danish government could step in to prevent Kalaallit Nunaat from becoming economically dependent on China: by this logic, even though infrastructure issues and development planning are under the authority of the Kalaallit Nunaat government, Denmark retains authority over foreign policy, and if Kalaallit Nunaat became economically dependent on another state, it would have geopolitical impacts. This threat from Denmark created consternation among Kalaallit Nunaat's political community, which regarded it as an effort to breach the distribution of authority under the Self-Government Act. Figures from across Kalaallit Nunat's own political spectrum responded defiantly that the Kalaallit Nunaat government had the power to select whatever contractor it wished to build its airports (Turnowsky, 2018; Holmsgaard, 2018; Breum, 2018a).

Ultimately, Danish fear of Chinese influence in Kalaallit Nunaat led to a startling change of heart: staunch Danish opposition to the airport package transformed into an agreement between the Danish and Kalaallit Nunaat governments for Denmark to supply 700 million Danish kroner (approximately $€ 94$ million) in equity as well as both a loan and a loan guarantee of 450 million Danish kroner (approximately $€ 60$ million) for the airport package (Breum, 2018a). As Breum (2018b; translation my own) notes, the Danish government's involvement in the airport package is "very likely not just about fear of Chinese influence in Greenland or making the project less risky for the Greenlandic economy [...] It at the very least represents a desire to retain Greenland in the Danish Realm." One Danish motivation for wishing to prevent Kalaallit Nunaat economic dependence on China or other states - as is also evident in Danish government efforts to prevent Chinese investment in other industries in Kalaallit Nunaat (e.g. Brøndum, 2016) - is simply to maintain Kalaallit Nunaat economic dependence on Denmark.

This was certainly the interpretation drawn by Partii Naleraq, a stridently proindependence political party that left the governing coalition in the Kalaallit Nunaat parliament in part as a result of the government's willingness to accept Danish financing for the airport package. In the words of Hans Enoksen, a former prime minister and current leader of Partii Naleraq, "The [Danish] state is interfering directly in [Kalaallit Nunaat] politics and thus casts doubt upon Kalaallit Nunaat's ability to do something ourselves. [...] Our goal has for a number of years been Kalaallit Nunaat independence, and when something like this is done, we can see that we're weakened" (qtd. in Ritzau, 2018e; translation my own). In contrast, another former 
Kalaallit Nunaat prime minister, Lars-Emil Johansen, believes that Danish investment in the airport package would bring the SNIJ closer to independence since it would make it easier to attract tourists and thus strengthen the economy (Fievé, 2018). (It is important to note that, prior to these events, Partii Naleraq and other parties in the governing coalition had been more broadly frustrated with a perceived lack of consultation regarding important decisions from Siumut party leader and Kalaallit Nunaat Prime Minister Kim Kielsen. That is, Parti Naleraq's departure from the government was not solely about opposition to accepting Danish financing for the airport package.)

At the time of writing, work on the airport package - and debate surrounding its impact on Kalaallit Nunaat's economic and political dependence or independence-continues. On 3 June 2019, the Chinese construction company CCCC announced it was withdrawing its bid for the airport package contract due to concerns about Danish interference in its bidding and eventual work processes, specifically regarding the ability of its engineers and other workers to obtain visas to Kalaallit Nunaat (a policy area under Danish control) (KNR, 2019).

The debate over the airport package marked a new era of USA government involvement in discussions of Kalaallit Nunaat's political status, with the USA Departments of State and Defense raising concerns about Chinese involvement in the project (Shi \& Lanteigne, 2019; Hinshaw \& Page, 2019). The stage was set for the 16 August 2019 revelation that USA President Donald Trump wished to purchase Kalaallit Nunaat from Denmark (Salama et al, 2019; Ritzau, 2019). Both academic researchers and political commentators were quick to place this in the context of fears that Kalaallit Nunaat would become economically dependent on China. Nils Wang, former Rear Admiral at the Royal Danish Defence College, stated:

Donald Trump is sending a signal to the Greenlandic politicians that they need to be careful about their economic dependence. Even though Chinese investments can be tempting, it can quickly become controversial in terms of security politics. The USA is concerned that China is creating some relationships of dependency in the Arctic (qtd. in Juncher Jørgensen, 2019a; translation my own).

Some Kalaallit Nunaat individuals and political parties are, however, beginning to challenge the interlinked political and economic dependence/independence binaries. On 29 August 2019, Partii Naleraq politician Pele Broberg (2019; translation my own) published a press release, entitled 'The time has come', arguing that Kalaallit Nunaat should use the USA's interest to explore means by which the territory might become politically independent while still securing economic support - from the USA. As Broberg expressed in a newspaper interview the same day, "An independent Kalaallit Nunaat will of course be dependent upon other countries, that's how it works these days. But the difference will be that we decide over our own country, and we can pursue our own foreign policy" (qtd. in Turnowsky, 2019b; translation my own). However, illustrating the persistence of binary conceptions Kalaallit Nunaat's political and economic relationships, Tillie Martinussen, a politician with Samarbejdspartiet (Kalaallit Nunaat's only explicitly unionist party), responded by stating, "A politically and economically independent Kalaallit Nunaat can only be achieved if/when we find new sustainable revenues, which can compensate for the Danish block grant to Kalaallit Nunaat as well as the billions in expenses in the justice area and our tasks within foreign and 
defense policy" (qtd. in Turnowsky, 2019c; translation my own). Martinussen's words bring to mind Carlsen's (2008, p.39) comment about the largely taken-for-granted "market liberalism or neoclassical thinking" underpinning so much of the imagination of Kalaallit Nunaat's potential economic and political futures.

Taken as a whole, quotes such as these illustrate the malleability of the concept of economic dependence, denoting something geopolitically positive or negative, conditional upon both who is speaking and who is dependent upon whom. The discourse of economic dependence thus becomes an element of wider struggles to define and determine colonially inflected power relationships.

\section{Kalaallit Nunaat: opportunities between dependencies?}

The overarching conceptual association between the economic dependence/independence binary and the political dependence/independence binary has previously been analysed by Gad (2017). Discussing Kalaallit Nunaat political discourse of the early 2000s, Gad (2017, p.56) identifies three "basic positions" underlying the apparent consensus in favour of independence:

One according to which self-governance was a precondition for [economic] selfsupport and another according to which self-support was a precondition for selfgovernance. Between these positions, a third and more complex construction of 'selfsupportedness' as a joint project shared by Greenland and Denmark meant that selfgovernment would remain a gradual affair.

As Gad (2017, p.59) notes, the outcome of the confrontation of these mutually exclusive notions regarding the relationship between economy and independence "is a deferral-or rather: a processualization - of the goal of self-government." Kalaallit Nunaat is perpetually stuck in a neither/nor position, continually in the midst of jurisdictional transformation, always preparing for a future that never quite arrives.

The conflation of economic linkages with political dependence is common among both proponents and opponents of Kalaallit Nunaat political independence. This is evident, for example, in the Greenland Business Association's (2019) implication, considered above, that Kalaallit Nunaat's present-day political autonomy is in fact illusory, that Kalaallit Nunaat's economic dependence means that the SNIJ only appears to be exercising political decisionmaking power.

The interlinking of the political and economic dependence/independence binaries proves very difficult for island territories to manage in practice. Although the sale of products and services of any kind implies that the consumers believe they are benefiting from their purchase, anecdotal experience suggests there has developed in Kalaallit Nunaat a disinclination to provide benefits to external actors. Rooted, no doubt, in the colonial experience and in the impression that Denmark continues to benefit from its relationship with Kalaallit Nunaat (Grydehøj, 2016a), there is a tendency in Kalaallit Nunaat's public discourse for overseas governments and businesses to be viewed with suspicion if they seek to profit from trade or engagement with the SNIJ.

The same suspicion exists for different reasons within the Danish public discourse regarding Kalaallit Nunaat. Thus, for example, in the case of the airport package, the benefit 
that 'China' (regarded as a monolithic state actor) could potentially accrue from the project was seen especially (though not exclusively) by Danish commentators as a signal that Kalaallit Nunaat risked making a bad deal. By the same token, however, a segment of the Kalaallit Nunaat population - as exemplified by Partii Naleraq's departure from government-regarded the securing of Danish benefit from the project as a signal that the SNIJ was once again being exploited by Denmark. Neither of these viewpoints is necessarily incorrect: after all, there may be good reasons for Kalaallit Nunaat to avoid tying itself to China, and it is true that Danish part-ownership over the airports decreases the Kalaallit Nunaat government's room to manoeuvre in terms of transport and ultimately other policy decisions.

What is critical here is that feelings of exploitation seem inevitable. In this context, Kalaallit concerns could simultaneously be raised not just about increased Danish involvement in the airport package (enhanced economic linking) but also about the Danish state's sale (Sermitsiaq, 2019) of its stake in Air Greenland to Kalaallit Nunaat (economic delinking): the associations between the political and economic dependence/independence binaries are so corrosive as to render every course of action-both engagement and disengagement-equally suspect. This aligns with the thinking of Emel, Huber, and Makene (2011, p.70), who argue that, particularly in postcolonial contexts in which natural resources are regarded as key to nationbuilding:

National sovereignty over territorial resources is often couched in opposition to foreign capital. [...] Rather than assuming resource sovereignty is necessarily territorially circumscribed and inwardly focused against 'outside' intervention, [...] we argue that national-scale sovereignty over resources emerged historically out of the global domination of capital and colonial-era attempts to construct intelligible swathes of territory (and resources) adjudicated through a sovereign, centralized state.

We should thus not be surprised that the discourses of the coloniser and the colonised resemble one another, even when they work against the interests of the former colony. In a situation in which "global 'external' forces" are seen to threaten "the purity of internal (often national) territorial sovereignty," (Emel, Huber, \& Makene, 2011, p.72), Kalaallit Nunaat's discourse of 'resource nationalism' emerges as yet another questionable inheritance of Danish colonialism. Such complex associations between nation and territory may furthermore be particularly intense in Indigenous island communities (Grydehøj, Nadarajah, \& Markussen, 2019).

This sets up a lose-lose scenario: as illustrated by the numerous popular, scholarly, and political communications considered in this paper, large segments of the island and metropolitan publics simultaneously regard relations of trade and mutual benefit as dangerous and exploitive while regarding receipt of aid and other direct transfers as inconsistent with political autonomy and independence. The pro-trade and globalisation perspective offered by the Greenland Business Association (2019) links up with this, asserting that Kalaallit Nunaat must engage internationally if its economy is to be strong but also suggesting that the creation of such overseas economic partnerships is incompatible with the kind of political independence that the people of Kalaallit Nunaat desire. Many Danish political actors reinforce this thinking, insisting (when speaking to a Danish public) that it is vital that Kalaallit Nunaat finds a means of paying its way without Danish beneficence-but then working (both overtly and covertly) to stymie Kalaallit Nunaat attempts to secure alternative sources of income from overseas. 
Although few if any Kalaallit politicians actually recommend cutting linkages with the outside world, the dangers of isolationism are used as a warning against Kalaallit Nunaat becoming economically independent from Denmark. It is suggested that there is no "innocent path to independence" (Breitenbauch, qtd. in Turnowsky, 2019; translation my own), as though the forging of alternative economic linkages were shameful or criminal. It is suggested that Kalaallit Nunaat risks ending up "in the pockets of the Chinese" (qtd. in Ritzau, 2018f; translation my own), as though Denmark were itself pocketless. It is suggested that the choice is between economic dependence on Denmark and, in the words of union leader Jess G. Berthelsen, going back to "shitting in a bucket" (qtd. in Kristensen, 2019a; translation my own), as though those were the only two options.

Yet whatever the protestations from Denmark, it is not at all clear that Denmark-Kalaallit Nunaat economic relations would shift substantially in the event that Kalaallit Nunaat one day became politically independent. The reasons why Denmark currently provides Kalaallit Nunaat with a block grant and other financial transfers as well as the reasons why Danish companies currently do business with Kalaallit Nunaat companies would not disappear on the day that Kalaallit Nunaat became a sovereign state. The Danish desire for a military (Forsvarsministret, 2019) and scientific research presence in the Arctic (Uddannelses- og Forskningsministret, 2019), the Danish desire to retain a voice in Arctic policymaking (Udenrigspolitisk Nævn, 2011)—these would remain. The Danish desire that Kalaallit Nunaat maintain its primary economic linkages with Denmark rather than with China, the USA, or another state would persist, regardless of Kalaallit Nunat's political status. And it would be up to policymakers and businesses in both Denmark and Kalaallit Nunaat to determine to what extent they wished to pursue these strategic interests and receive payment for providing them respectively.

As Bertram and Watters (1984, p.124) note in the context of New Zealand's relationship with Pacific island territories, "The extent to which economic dependence is a fetter on political independence depends on the degree to which the dominant power exercises the power it possesses." Given that there is no absolute link between economic and political independence, a Kalaallit Nunaat decision to transition from an SNIJ to an SIS would not absolve Denmark of the responsibility for making choices about its future economic relationship with its former colony. Similarly, such a transition would not automatically reduce the leverage that Kalaallit Nunaat possesses in its relationship with Denmark.

\section{Conclusion}

The assertion that Kalaallit Nunaat must either remain (negatively) economic dependent on Denmark or learn to be economically independent is particularly troublesome because the standard economic and development policy advice given to Kalaallit Nunaat by the Danish government and Danish experts subjects the SNIJ to conditions and strategies that would be either impossible or extremely painful to achieve (Grydehøj, 2018a). In accordance with the binary logics, this means that Kalaallit Nunaat is trapped in political dependence and economic dependence and that the people of Kalaallit Nunaat ought to feel bad about it. The SNIJ's status quo is thus presented as a normative or ethical failure (see also Bertram \& Watters, 1984, p.117; Poirine, 1998, p.76).

In reality, however, the Kalaallit Nunaat government's ability to forge economic links with China, USA, Denmark, and other states should not be regarded as evidence of negative 
political and economic dependence. It would make more sense to interpret this as evidence of Kalaallit Nunaat's capacity for independent policymaking. After all, the Kalaallit Nunaat government has constructed conditions that enable it to choose between potential economic partners.

Kalaallit Nunaat's current economic dependence on Denmark is only a marker of negative dependence (rather than positive linkage) if Kalaallit Nunaat has no other choice. However, Kalaallit Nunaat is capable - in both law and in practice-of engaging in trade with and receiving transfers from not just Denmark but also other overseas business and state actors. When circumstances are such that the Danish government feels pressured into providing economic support for a Kalaallit Nunaat infrastructure project, it actually points to Kalaallit Nunaat possessing a significant degree of economic independence. As Tita (2014, p.1), argues, a key benefit of political authority is precisely the ability to develop "a strong economy through the establishment of solid partnerships with external polities, regardless the level of economic dependence that this implies," thereby increasing "the opportunity of gaining external assistance from those partners with whom strategic economic interests are shared."

The oversimplified economic dependence/independence binary and political dependence/independence binary have become mutually constitutive: economic independence and political independence are presented as preconditions for one another-and thereby impossible to achieve. You are either 'in', or you are 'out'. Under this flawed logic, if an SNIJ wishes to become politically independent, it must first support itself; yet also under this flawed logic, supporting itself requires severing the links of international trade and intergovernmental relations that are the hallmarks of actual sovereign states. Meanwhile, the true political independence of SISs and the true autonomy of SNIJs are liable to be called into question if these territories possess strong economic linkages, even though open economies are precisely what sovereign states are advised to pursue. The economic expectations placed on SNIJs and SISs are often so unrealistic or unpalatable as to suggest that they have been defined in such a manner as to be unfulfillable (Grydehøj, 2018b).

In the case of Kalaallit Nunaat, the association between the two binaries serves as a source of inertia, reinforcing the attractiveness of the status quo. A majority of Kalaallit Nunaat's population desires weaker economic and political dependence on Denmark, but there is no groundswell of opinion in favour of isolation. There is instead a desire for Kalaallit Nunaat to make its own decisions. This must include decisions to enter into mutually beneficial economic relationships and relations of economic dependence.

By looking beyond the binaries, publics and policymakers in both island territories and the numerous mainland societies with which they are linked can come to identify new sources of economic strength and can draw the poison from existing economic relationships that have been turned toxic by colonial or otherwise oppressive history and experience.

\section{Acknowledgments}

I wish to thank Astrid Nonbo Andersen, Javier Arnaut, Aká Bendtsen, Danita Catherine Burke, Kuno Fencker, Ulrik Pram Gad, Carina Ren, Kirsten Thisted, and Lars Villadsen for reviewing earlier drafts of this paper and for providing comments and criticisms that have both strengthened the paper's scholarly rigour and made it more attentive to particular circumstances within Kalaallit Nunaat. All mistakes remain my own. 


\section{References}

Agee, J. (2009). Developing qualitative research questions: a reflective process. International Journal of Qualitative Studies in Education, 22(4), 431-447. https://doi.org/10.1080/09518390902736512

Agnew, J. (1994). The territorial trap: The geographical assumptions of international relations theory. Review of International Political Economy, 1(1), 53-80. https://doi.org/10.1080/09692299408434268

Alberti, F., \& Goujon, M. (2020) A composite index of formal sovereignty for small islands and coastal territories. Island Studies Journal, 15(1), forthcoming. https://doi.org/10.24043/isj.96

Appadurai, A. (1996). Sovereignty without territoriality: Notes for a postnational geography. In P. Yaeger (Ed.). The geography of identity (pp.40-58). Ann Arbor: University of Michigan Press.

Armstrong, H. W., \& Read, R. (2003). Small states, islands and small states that are also islands. Studies in Regional Science, 33(1), 237-260. https://doi.org/10.2457/srs.33.237

Baldacchino, G. (2010). Island enclaves: offshoring strategies, creative governance, and sub-national island jurisdictions. Montréal: McGill-Queen's University Press.

Baldacchino, G., \& Hepburn, E. (2012). A different appetite for sovereignty? Independence movements in subnational island jurisdictions. Commonwealth \& Comparative Politics, 50(4), 555-568. https://doi.org/10.1080/14662043.2012.729735

Baldacchino, G., \& Milne, D. (eds.) (2009). The case for non-sovereignty: Lessons from sub-national island jurisdictions. London: Routledge.

Bertram, G. (2015). Is independence good or bad for development in small island economies? A long-run analysis. Region et Developpement, 42(1), 31-54.

Bertram, I. G., \& Watters, R. F. (1984). New Zealand and its small island neighbours: a review of New Zealand policy toward the Cook Islands, Niue, Tokelau, Kiribati and Tuvalu. Institute of Policy Studies Working Paper, 84(01).

Bjørst, L. R., \& Ren, C. (2015). Steaming up or staying cool? Tourism development and Greenlandic futures in the light of climate change. Arctic Anthropology, 52(1), 91-101. https://doi.org/10.3368/aa.52.1.91

Bonilla, Y. (2017). Unsettling sovereignty. Cultural Anthropology, 32(3), 330-339.

Brańka, T. (2018). Greenland-from Autonomy to (In) Dependence. Przegląd Strategiczny, 11, 107-128. https://doi.org/10.14746/ps.2018.1.8

Breum, M. (2019, January 9). Martin Breum: Her er den egentlige forskel på dansk og grønlandsk syn på fremtiden. Altinget. Retrieved from https://www.altinget.dk/arktis/artikel/martin-breum-her-er-den-egentlige-forskel-paadansk-og-groenlandsk-syn-paa-

fremtiden?fbclid=IwAR1Un6Sg4NZLwwnLi afS9ffQxvMUKNfmwfvreSHegoA2CM 4uPTwTKiavBM

Breum, M. (2018a, September 24). Danmarks uklare sikkerhedskurs i Nordatlanten. Martinbreum.dk. Retrieved from http://www.martinbreum.dk/danmarks-uklaresikkerhedskurs-nordatlanten/

Breum, M. (2018b). Hvad er motivet bag Danmarks statsminister og Grønlands lufthavne?. High North News, 7 November. https://www.highnorthnews.com/nb/hvad-er-motivet-bagdanmarks-statsminister-og-gronlands-lufthavne 
Broberg, P. (2019, August 29). Tiden er inde. Naleraq.gl. Retrieved from https://naleraq.gl/da/seneste-nyheder/tiden-er-inde/

Brøndum, C. (2016, December 16). Danmark forhindrer kinesisk opkøb af marinebase i Grønland. Nordic Defence Watch. Retrieved from http://www.defencewatch.dk/danmark-forhindrer-kinesisk-opkoebmarinebasegroenland/

Cardoso, F. H., \& Faletto, E. (1979). Dependency and development in Latin America. M. M. Urquidi (Trans.). Berkley: University of California Press.

Carlsen, A.V. (2008). Et postkolonialt arktisk arbejdsmarked - en udfordring for grønlandsk fagbevægelse. Økonomi \& Politik, 81(4), 38-54.

Emel, J., Huber, M. T., \& Makene, M. H. (2011). Extracting sovereignty: Capital, territory, and gold mining in Tanzania. Political Geography, 30(2), 70-79. https://doi.org/10.1016/j.polgeo.2010.12.007

Ferdinand, M., Oostindie, G., \& Veenendaal, W. (2020). A global comparison of non-sovereign island territories: the search for 'true equality'. Island Studies Journal, 15(1). Epub ahead of print. https://doi.org/10.24043/isj.75

Fievé, J. (2018, November 15). Lars-Emil Johansen: Mittarfiit pingasuusut namminiilivinnissamut qanillattorteqqissavaatigut.

KNR. https://knr.gl/kl/nutaarsiassat/mittarfiit-pingasuusut-namminiilivinnissamutqanillattorteqqissavaatigut

Forsvarsministret (2019). Opgave i Arktis og Nordatlanten. Forsvarsministret. Retrieved from https://www.fmn.dk/videnom/Pages/OpgaveriArktisogNordatlanten.aspx

Gad, U. P. (2017). National identity politics and postcolonial sovereignty games: Greenland, Denmark, and the European Union. Copenhagen: Museum Tusculanum.

Ghai, Y., \& Regan, A. J. (2006). Unitary state, devolution, autonomy, secession: State building and nation building in Bougainville, Papua New Guinea. The Round Table, 95(386), 589608. https://doi.org/10.1080/00358530600931178

Greenland Business Association (2019). Economic independence and political autonomy. What will it take? Future Greenland. Retrieved from http://www.futuregreenland.gl/en$\mathrm{gb} /$ The-purpose-of-the-conference

Grimm, D. (2015). Sovereignty: The origin and future of a political and legal concept. B. Cooper (trans.). New York: Columbia University Press.

Grønvold Samuelsen, P. (2010). Grønlandsk ledelseskultur - en analyse af ledelse i Grønland. MA thesis, Ilisimatusarfik.

Grydehøj, A. (2018a). Decolonising the economy in micropolities: rents, government spending and infrastructure development in Kalaallit Nunaat (Greenland). Small States \& Territories, 1(1), 69-94.

Grydehøj, A. (2018b). Hearing voices: Colonialism, outsider perspectives, island and Indigenous issues, and publishing ethics. Island Studies Journal, 13(1), 3-12. https://doi.org/10.24043/isj.54

Grydehøj, A. (2016a). Navigating the binaries of island independence and dependence in Greenland: Decolonisation, political culture, and strategic services. Political Geography, 55, 102-112. https://doi.org/10.1016/j.polgeo.2016.09.001 
Grydehøj, A. (2016b). Toward subnational democracies of scale: Tensions between democratic legitimacy, legality, and effective governance. Geopolitics, 21(1), 22-42. https://doi.org/10.1080/14650045.2015.1114918

Grydehøj, A., Nadarajah, Y., \& Markussen, U. (2019). Islands of indigeneity: Cultural distinction, indigenous territory and island spatiality. Area. Epub ahead of print. https://doi.org/10.1111/area.12520

Frank, A. G. (1969). Latin America: Underdevelopment or revolution - Essays on the development of underdevelopment and the immediate enemy. New York \& London: Monthly Review Press. https://doi.org/10.1017/s0022050700091142

Frank, A. G. (1967). Capitalism and underdevelopment in Latin America. New York \& London: Monthly Review Press.

Hannestad, A. (2014, January 23). 13 eksperter skyder Grønlands drøm om selvstændighed i sænk. Politiken. https://politiken.dk/oekonomi/dkoekonomi/art5499005/13-eksperterskyder-Gr\%C3\%B8nlands-dr\%C3\%B8m-om-selvst\%C3\%A6ndighed-i-s\%C3\%A6nk

Hansen, K. G. (2017). Fra passiv iagttager til aktiv deltager. Nuuk: Naalakkersuisut.

Hansen, K. G. (2013). The aluminium smelter project in Greenland - New aspects of an industrialisation process? In K.G. Hansen, S. Bitsch, \& L. Zalkind (Eds) Urbanization and the role of housing in the present development process in the Arctic (pp.85-101). Stockholm: Nordregio.

Hinshaw, D., \& Page, J. (2019, February 10). How the Pentagon countered China's designs on Greenland. Washington Post. Retrieved from https://www.wsj.com/articles/how-thepentagon-countered-chinas-designs-on-greenland-11549812296

Holmsgaard, E. (2018). Kinaskak om nye lufthavne. Aurora, 2018(2), 20-25.

Information (2002, June 10). Grønland vil selv, men kan ikke. Information. Retrieved from https://www.information.dk/2002/06/groenland-kan?vwo exp badges $=|32|$

Juncher Jørgensen, T. (2019a, August 23). Arktis har topprioritet. Sermitsiaq, p. 22.

Juncher Jørgensen, T. (2019b, June 28). Løsrivelse fra Danmark har en pris. Sermitsiaq, p. 10.

Kalaallit Airports Holding (2019). Uagut pilluta. Kalaallit Airports Holding. http://kair.gl/kl/kalaallit-airports-holding-a-s-2/uagut-pilluta/

KNR (2019, June 3). Sermitsiaq.AG: Kinamiut ingerlatseqatigiiffissuat nunatsinni mittarfiliortiternissamit tunuarterpoq. KNR. Retrieved from https://knr.gl/kl/nutaarsiassat/kinamiut-ingerlatseqatigiiffissuat-nunatsinnimittarfiliortiternissamit-tunuarterpoq

Korson, C. (2018). (Re)balancing Inequality through Citizenship, Voter Eligibility and Islandian Sovereignty in Kanaky/New Caledonia. Geopolitics. Epub ahead of print. https://doi.org/10.1080/14650045.2018.1543270

Kristensen, K. (2019a, July 6). Aaqqissuisuuneq innersuussivoq: Ikinnerpaat siparnimi anartarusupput. Sermitsiaq.ag. Retrieved from https://sermitsiaq.ag/kl/aaqqissuisuuneqinnersuussivoqikinnerpaat-siparnimi-anartarusupput

Kristensen, K. (2019b, July 26). Forfatning og økonomi kører hvert sit løb. Sermitsiaq, 6-7.

Kristensen, K. (2019c, July 5). Ujakkat: 5 milliarder koruunit. Sermitsiaq, 12-13.

Lindsrøm, M. (2019, June 25). Jo mere vi ved om landets økonomi, desto mindre ønsker vi selvstændighed. KNR. Retrieved from https://knr.gl/da/nyheder/jo-mere-vi-ved-omlandets-\%C3\%B8konomi-desto-mindre-\%C3\%B8nsker-vi-selvst $\% \mathrm{C} 3 \% \mathrm{~A} 6$ ndighed 
McElroy, J. L., \& Parry, C. E. (2012). The long-term propensity for political affiliation in island microstates. Commonwealth \& Comparative Politics, 50(4), 403-421. https://doi.org/10.1080/14662043.2012.729727

McElroy, J. L., \& Pearce, K. B. (2006). The advantages of political affiliation: Dependent and independent small-island profiles. The Round Table, 95(386), 529-539. https://doi.org/10.1080/00358530600931285

Macnamara, J. R. (2005). Media content analysis: Its uses, benefits and best practice methodology. Asia Pacific Public Relations Journal, 6(1), 1-34.

Naalakkersuisut (2018). Mittarfiit ataatsimoortitat. Naalakkersuisut. Retrieved from https://naalakkersuisut.gl/kl-GL/Naalakkersuisut/Naalakkersuisoqarfiit/Boliger-ogInfrastruktur/Lufthavnspakken

Olesen, S. M. (2017). Et helligt hverv-Grønlands afkolonisering, 1945-54. Temp-tidsskrift for historie, 7(13), 152-176.

Pugh, J. (2017). Postcolonial development, (non) sovereignty and affect: Living on in the wake of Caribbean political independence. Antipode, 49(4), 867-882. https://doi.org/10.1111/anti.12305

Pöllath, M. (2018). Revisiting island decolonization: The pursuit of self-government in Pacific island polities under US hegemony. Island Studies Journal, 13(1), 235-250. https://doi.org/10.24043/isj.46

Ratter, B. M. W. (2018). The geography of small islands: Outposts of globalisation. Cham: Springer.

Ritzau (2019, August 18). Uppernarsarneqarpoq: Trumpip Kalaallit Nunaata pisiarineqarsinnaanera misissorpaa. Sermitsiaq.ag. Retrieved from https://sermitsiaq.ag/kl/uppernarsarneqarpoqtrumpip-kalaallit-nunaatapisiarineqarsinnaanera-misissorpaa

Ritzau (2018a, January 19). DF-ordfører: Grønland styrer mod økonomisk kollaps. B.T. Retrieved from https://www.bt.dk/politik/df-ordfoerer-groenland-styrer-modoekonomisk-kollaps

Ritzau (2018b, March 26). Kalaallit Airports: Suliaqartartut arfinillit mittarfiliortitsinissamut neqeroortinneqassapput. Sermitsiaq.ag. Retrieved from https://sermitsiaq.ag/kl/kalaallitairportssuliaqartartut-arfinillit-mittarfiliortitsinissamut-neqeroortinneqassapput

Ritzau (2018c, January 19). Løkke: Kalaallit Nunaat namminersortoq aningaasaqarnikkut namminiissaaq. Sermitsiaq.ag. Retrieved from https://sermitsiaq.ag/kl/lokke-kalaallitnunaat-namminersortoq-aningaasaqarnikkut-namminiissaaq

Ritzau (2018d, May 24). Løkke advarer Grønland mod at lade Kina bygge lufthavne. Fyens stiftstidenede. Retrieved from https://www.fyens.dk/indland/Loekke-advarer-Groenlandmod-at-lade-Kina-bygge-lufthavne/artikel/3258403

Ritzau (2018e, September 9). Partii Naleraq forlader Grønlands regering efter lufthavnsstrid. B.T. Retrieved from https://www.bt.dk/samfund/partii-naleraq-forlader-groenlandsregering-efter-lufthavnsstrid

Ritzau (2018f, May 25). S: Grønland må ikke ende i lommen på kineserne. Berlingske. Retrieved from https://www.berlingske.dk/politik/s-groenland-maa-ikke-ende-i-lommen-paa-kineserne

Rottbøll, E. (2018, March 13). Selvstændigheden er jeres, Grønland - hvad vil I bruge den til?. Information. Retrieved from https://www.information.dk/udland/leder/2018/03/selvstaendigheden-jeres-groenland-bruge 
Salama, V., Ballhaus, R., Restuccia, A., \& Bender, M. C. (2019, August 16). President trump eyes a new real-estate purchase: Greenland. The Wall Street Journal. https://www.wsj.com/articles/trump-eyes-a-new-real-estate-purchase-greenland$\underline{11565904223}$

Sassen, S. (2008). Territory, authority, rights: From medieval to global assemblages. Princeton: Princeton University Press. https://doi.org/10.1162/jinh.2008.38.3.434

Sermitsiaq (2019, May 29). Air Greenlandip aktiaanik pisinissamut isumaqatigiissut inissippoq. Sermitsiaq.ag. Retrieved from https://sermitsiaq.ag/kl/air-greenlandip-aktiaanikpisinissamut-isumaqatigiissut-inissippoq

Sermitsiaq (2014, January 24). Ekspert: Rapport kan blive benzin på bålet. Sermitsiaq. Retrieved from https://sermitsiaq.ag/kl/node/163014

Shi, M., \& Lanteigne, M. (2019, June 10). A cold arena? Greenland as a focus of Arctic competition. The Diplomat. Retrieved from https://thediplomat.com/2019/06/a-coldarena-greenland-as-a-focus-of-arctic-competition/

Skydsbjerg, H., \& Turnowsky, W. (2016, December 1). Namminiilivinnissamut angertut amerlanerussuteqarluartut. $\quad$ Sermitsiaq.ag. $\quad$ Retrieved from https://sermitsiaq.ag/kl/node/192285.

Tita, G. (2014). Coping with inherent vulnerabilities and building resilience in small islands: Socioeconomic and governance perspectives. Havre-aux-Maisons: Centre de Recherche sur les Milieux Insulaires et Maritimes.

Turnowsky, W. (2019a, May 14). Analytiker: Uafhængighed fra Danmark vil give afhængighed af USA. Sermitsiaq.ag. Retrieved from https://sermitsiaq.ag/node/213607

Turnowsky, W. (2019b, August 29). Pele: Vil USA hjælpe os til frihed fra Danmark?. Sermitsiaq.ag. Retrieved from https://sermitsiaq.ag/node/215721

Turnowksy, W. (2019c, August 30). Tillie til Pele: Du vil sælge landets sjæl til Trump. Sermitsiaq.ag. Retrieved from https://sermitsiaq.ag/node/215748

Turnowsky, W. (2018, June 1). Aleqa: Kinamik suleqateqarnissaq pillugu danskit naalakkersuisui akuliupput. Sermitsiaq.ag. Retrieved from https://sermitsiaq.ag/kl/aleqakinamiksuleqateqarnissaq-pillugu-danskit-naalakkersuisui-akuliupput

Turnowksy, W. (2017a, April 1). Ajornerulertoqassanngippat aatsaat namminersulivikkusupput. Sermitsiaq.ag. Retrieved from https://sermitsiaq.ag/kl/ajornerulertoqassanngippat-aatsaatnamminersulivikkusupput

Tunrowsky, W. (2017b, June 15). Kalaallit namminiilivinniarnerat Løkkep aatsaat qaqugorsuarmut pissangatippaa. Sermitsiaq.ag. Retrieved from https://sermitsiaq.ag/kl/kalaallitnamminiilivinniarnerat-lokkep-aatsaat-qaqugorsuarmut-pissangatippaa

Uddannelses- og Forskningsministret (2019). Status på Handlingsplanen: Strategi for forskning og uddannelse vedrørende Arktis. Uddannelses- og Forskningsministret. Retrieved from https://ufm.dk/forskning-og-innovation/internationalt-

$\underline{\text { samarbejde/polarsamarbejder/strategien/status-pa-handlingsplanen-strategi-for- }}$ forskning-og-uddannelse-vedrorende-arktis

Udenrigspolitisk Nævn (2011). Danmark, Grønland \& Farøerne: Kongeriget Danmarks strategi for Arktis 2011-2020. København, Nuuk, Tórshavn: Udenrigspolitisk Nævn.

Villadsen, L. (2016). Har Gronland en kollektiv nationalidentitet? Nationsbygning i det selvstyrede Grønland. MA thesis, Ilisimatusarfik. 
Wennecke, C. W., Jacobsen, R. B., Ren, C. (2019). Motivations for Indigenous island entrepreneurship: Entrepreneurs and behavioral economics in Greenland. Island Studies Journal, 14(2). Epub ahead of print. https://doi.org/10.24043/isj.99

Winther, G. (2018, April 26). Grønlandsk selvstændighed ligner "valgspæk«, så længe man er helt afhængig af danske kroner. Berlingske. Retrieved from https://www.berlingske.dk/kronikker/groenlandsk-selvstaendighed-ligner-valgspaeksaa-laenge-man-er-helt-afhaengig-af

Yuen, S. (2015). Hong Kong After the Umbrella Movement: An uncertain future for 'One Country Two Systems'. China Perspectives, 2015(1), 49-53.

Økonomisk Råd (2014). Grønlands Økonomi 2014. Nuuk: Økonomisk Råd. 